\title{
Critical Determinants of Technological Innovation: A Conceptual Framework and a Case Study from Iraq
}

\author{
Abdul Qadir Rahomee Ahmed Aljanabi ${ }^{1}$ \& Nor Azila Mohd Noor ${ }^{1}$ \\ ${ }^{1}$ Othman Yeop Abdullah Graduate School of Business, University Utara Malaysia, Sintok, Malaysia \\ Correspondence: Abdul Qadir Rahomee Ahmed Aljanabi, Othman Yeop Abdullah Graduate School of \\ Business, University Utara Malaysia, Sintok, Malaysia. Tel: 601-4625-8962. E-mail: janabi76@gmail.com
}

Received: November 10, 2014

Accepted: November 25, $2014 \quad$ Online Published: January 25, 2015

doi:10.5539/ibr.v8n2p16

URL: http://dx.doi.org/10.5539/ibr.v8n2p16

\begin{abstract}
This paper presents a conceptual framework to explore the mechanisms between knowledge sharing and market orientation with a case study from Iraqi industrial SME. This paper attempts to practically justify the presented framework by investigating the relation between knowledge sharing dimensions, in addition to analyzing the mutual relation between knowledge sharing and market orientation and their contribution in fostering technological innovation. This study asserts the effective role of customers in generating of knowledge for firms' technological innovation. Further, this study provides a complementary perspective between knowledge sharing and market orientation by highlighting customers' role in generating the required knowledge for innovation and the role of knowledge sharing among employees in achieving responsiveness to customers' needs. For practitioners, this paper hopes to help enterprises to obtain deeper understanding of linking mechanisms and recognize the advantages of gathering and generating knowledge about customers and markets, and share this knowledge among all members of the firm to enhance technological innovation.
\end{abstract}

Keywords: technological innovation, knowledge sharing, market orientation

\section{Introduction}

The ability to obtain new knowledge and exploit the prior one represents one of the most important success factors for today's firm in their quest to develop new products and processes. Knowledge-based view (KBV) theoreticians propose that the ability to gather, generate, disseminate and share knowledge are of the basic pillars for achieving competitive advantage for the firms (Nickerson \& Zenger, 2004; Szulanski, Cappetta, \& Jensen, 2004) which is fundamental to enhance technological innovation (e.g., product and process innovation). Firms, while seeking to gather related Knowledge from various sources, such knowledge cannot be of value in the long term unless it is shared and disseminated among all members of the organization. SMEs on the other hand are intrinsically characterized as more innovative, particularly in the early phases of the industry lifecycle (Bakar \& Ahmad, 2010; Bouncken \& Kraus, 2013). Smaller firms have a higher tendency to interact more with their customers, be more flexible and more proactive compared to larger firms. These differences could provide significant opportunities for examining the role of sharing the knowledge in achieving innovation in smaller firms. In fact, there is little knowledge about how Iraqi industrial SMEs conduct knowledge sharing (KS) and market orientation (MO) to enhance their technological innovation (TI). Consequently, this study investigates whether the KS and MO practices in Iraqi industrial SMEs foster the TI in such developing economy. In doing so, we develop a conceptual framework to comprehend the relations mechanisms between investigated dimensions. Then case study technique utilized to validate this conceptual framework. The rest of this study is organized as follows: reviewing related literature and developing research propositions; the case subject and data collection have been described in research method; result from the case study are presented in deductive testing of propositions, then the findings summary end our study in addition to theoretical contributions, implications and limitations of this study and future prospects.

\section{Literature Review}

\subsection{Technological Innovation}

Business innovation phenomenon was first initiated in the early human settlements and it has since affected civilizations and cultures (Inauen \& Schenker-Wicki, 2011). Nowadays, firms are facing great increase in 
customer's requirements and needs more than ever before. In the midst of such circumstances, successful organizations are those who are capable of satisfying customer's needs optimally and not those who are only determine these needs. To achieve such a feat, innovation is considered as a suitable mean to achieve competitive advantage as it represents a power for today's organizations (Kamasak \& Bulutlar, 2010; Otero-Neira, Lindman, \& Fernández, 2009).

So far as Kamasak and Bulutlar (2010) reported, innovation is best understood as generation, adoption and implementation of new ideas, policies, programs, process, product/service to the organization that adopting it. Meanwhile, Crossan and Apaydin (2010) developed a comprehensive definition of innovation - they defined it as the generation or adoption, assimilation and use of value-added, new invention in the economic and social field that realizes the renewal and enlargement of products and development of novel production techniques, and the establishment of new systems of management. It is process as well as outcomes. Various innovation types are highlighted in literature. The most widely accepted classification is the one brought forward by Damanpour (1991), wherein he differentiates between TI and administrative form of innovations. TI refer to novel processes, products and services while in administrative form point out to novel procedures and policies, and it is covered under the umbrella of non-technical innovation (Jiménez-Jiménez \& Valle, 2011; Ngo \& O'Cass, 2013). Technological innovation has been acknowledged as the substantial type for manufacturing enterprises given to its abilities to provide added value to their customers, enhancing firm's performance and fostering competitive advantage, as stated by (Lee, Leong, Hew, \& Ooi, 2013).

As regard to the SMEs, literatures argued that these enterprises possess certain features including; less bureaucratic, higher tendency to take risks, possession of a more specialized knowledge, faster reactions to the dynamic market demands. These characteristics allow SMEs to gain from external knowledge more effectively compared to their larger counterparts (Bigliardi \& Dormio, 2009; Westerberg \& Frishammar, 2012). Thus, they will have a significant effect on the growth and innovation activities.

Scholars have supported that product and process innovation represent the essential dimensions of TI (Camisón \& Villar-López, 2012; Liu \& Cui, 2012) that supposed to be investigated in in current research. Product innovations deemed as utilizing of current knowledge that depends on actual experiences to achieve new outputs that redeem the present and potential needs of customers (Cheng, Chang, \& Li, 2012; Lee et al., 2013). Whereas, process innovation defined as an employment of new methods or improvement of production or delivery techniques, and it may relate to changes in equipment, human resources, working methods or a combined version of all (Bear \& Frese, 2003; OECD, 2005).

\subsection{Knowledge Sharing}

Knowledge sharing is considered one of the most important elements of knowledge management, and it is as "deliberate efforts occurring with the existence of sufficient willingness of individuals to participate their own experience, skills and knowledge with their colleagues to foster organizational Knowledge" (Aljanabi \& Kumar, 2012). KS can also be seen as a process of the transfer of all kinds of knowledge that derives its importance from its role in linking both the individual and organizational levels (Sánchez, Sánchez, Collado-Ruiz, \& Cebrián-Tarrasón, 2013; Sohail \& Daud, 2009), through social networks as an ideal context for creation and dissemination of knowledge (Hoarau \& Kline, 2014). KS has two dimensions; donating, and collecting of knowledge. Knowledge donating define as the voluntary communication between people to transfer information, while knowledge collecting represents attempting to consulting colleagues to encourage each other to share what they know (Aljanabi \& Kumar, 2012; Kamasak \& Bulutlar, 2010).

KS is not considered an end in itself but a means to achieve farthest organizational goals, within this vein, a number of researches (Casimir, Lee, \& Loon, 2012; Hooff, Schouten, \& Simonovski, 2012; Sohail \& Daud, 2009) reported that applying of KS practices have a significant role in improving innovation process as an outcome of knowledge dissemination among the individuals within the firms. In spite of that, individuals have complete domination on their knowledge, thus, the decision on whether or not to exchange of knowledge is subject to the extent of benefit from the exchange process (Casimir et al., 2012), which means that the relationship between individuals represent the focal point of knowledge sharing behavior, consequently, KS result from voluntary behavior and cannot be forced (Hooff et al., 2012)

\subsection{Market Orientation}

Market orientation is attemptan to gather, disseminate, and manage invaluable information from external stakeholders, including customers and competitors, in hopes of better organizing internal activities (Celuch \& Murphy, 2010; Foley \& Fahy, 2009). Scholars have agreed that MO comprised of the following dimensions: intelligence generation, intelligence dissemination, and responsiveness (Boso, Cadogan, \& Story, 2012; 
Grinstein, 2008a; Kohli \& Jaworski, 1990). Market orientation scholars have argued extensively the significance and benefits of employing MO, specifically, Grinstein (2008b); Tsiotsou and Vlachopoulou (2011) deemed MO as the internal power that reinforces organization Figure1. Conceptual Frameworks in their achievement of sustainable competitive advantage through adding superior value into new products and services (Zahra, 2008). This value can be achieved by understanding the present and potential customer needs (Sen, 2010). In addition, $\mathrm{MO}$ is deemed to motivate the generation of new knowledge regarding customers and competitors and in turn, this results in knowledge-questioning values (Grinstein, 2008b; Jiménez-Jimenez, Valle, \& Hernandez-Espallardo, 2008) and it is an important enabler of competitive advantage, particularly in case of SMEs (Celuch \& Murphy, 2010; Zahra, 2008), that because organization's sustainable competitive advantage stems from an integral group of crucial internal and external assets, and MO produces such advantage (Jiménez-Jimenez et al., 2008) which leads to the development of shared value, products and services that promotes firm growth (Wang \& Chung, 2013). This is the reason why market-oriented organization exists and survives (Tsiotsou \& Vlachopoulou, 2011). Based on the above discussion, it can be concluded that MO has become a crucial element for organizations, particularly as a means to accumulate knowledge through the activation of previous knowledge and its combination with new knowledge obtained from external environment. This adds new value to customers, improves the process of innovation and promotes competitive advantage.

\subsection{A Conceptual Framework}

A wide stream of literature argued that knowledge is an essential bundle of intangible resources that can be the stimulus for innovation (Hall \& Andriani, 2003; Lee et al., 2013; Sánchez et al., 2013). They acknowledged in fact, that knowledge has the greatest power of all resources to serve as a main source of innovation. Given to its immobility, inclusive applicability, ambiguity, complexity, and tacitness, Knowledge allows the firm to expect the nature and attitudes of commercial changes and to predict the suitable reaction more accurately (Cohen \& Levinthal, 1990; Wang \& Han, 2011; Wiklund \& Shepherd, 2003). KBV scholars assert that firms should support techniques to effectively generate, partake, and spread knowledge grasped in their daily processes. Firms cannot adapt and develop innovative processes, products unless they employing and take advantage of the common and mutual information of their staffs (Aljanabi \& Kumar, 2012; Zahra, Neubaum, \& Larrañeta, 2007).

On the other hand, MO has been studied extensively as stimulus for innovation; substantial body of research has focused on its different roles in new product and process success (Beck, Janssens, Debruyne, \& Lommelen, 2011; Wang \& Chung, 2013; Zhang \& Duan, 2010). None of the former studies has investigated the mutual relationship between KS and MO and their role in harnessing technological innovation. Hence, this study attempts to fill this theoretical and empirical gap by investigating the linkage mechanism between KS, MO and their contributions on TI (see Figure1.).

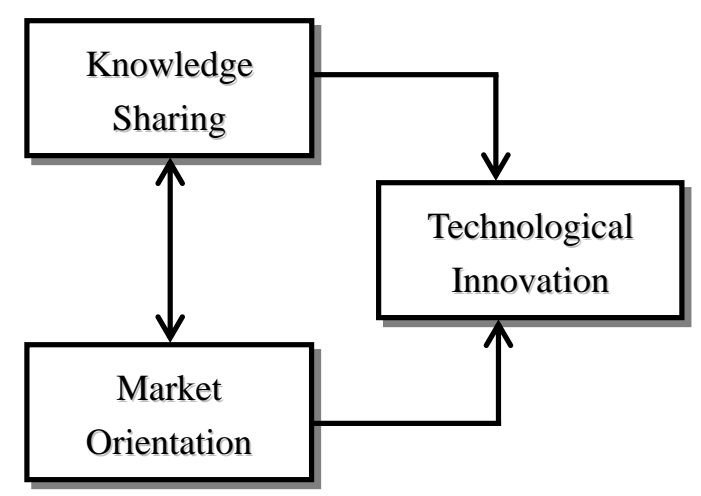

Figure 1. Conceptual framework

\section{Research Propositions}

In light of the previous discussion for related literature and incorporating the proposed conceptual framework, the following propositions are considered.

\subsection{Knowledge Sharing and Technological Innovation}

Referring to the past literature, researchers concur that innovation is dependent heavily on the creation of new knowledge (Hoarau \& Kline, 2014; Kamasak \& Bulutlar, 2010), which is often result from the sharing of 
knowledge (Aljanabi \& Kumar, 2012; Lee et al., 2013). However, Capon, Farley, Lehmann, and Hulbert (1992) found out that firm's ability to innovate did not significantly affected by obtaining new information from other enterprises. Nevertheless, scholars reported that KS represent a substantial determinant to enhance enterprises' innovation as the appropriate way of exchanging information among enterprises' members raises a firm's access to new knowledge (Lee et al., 2013; Lin, 2007; Wu, Guo, \& Shi, 2013). Thus we posit,

Proposition 1. Knowledge sharing mainly contributes to technological innovation by enhancing products and process that meet customers'needs

\subsection{Knowledge Sharing and Market Orientation}

Researchers have identified knowledge acquisition as a power to foster knowledge generation and dissemination in the firms (Zahra \& George, 2002; Zahra et al., 2007) it represents the starting point for employees learning process (Li, Wei, \& Liu, 2010). Hung, Lien, Fang, \& McLean (2010) argued that enterprises have a try to combine their information by rig out advantageous conditions to knowledge participation among individuals to obtain elevated grade of innovation. In a more elaborated insight, intelligence dissemination as a dimension of MO pertains to knowledge sharing among various sections and firm members (Zhang \& Duan, 2010; Beck et al., 2011; Chung, 2012) and the exchange of ideas produced from intelligence among departments and individuals in an organization through formal and informal methods (Chao \& Spillan, 2010), both horizontal and vertical ways (Chung, 2012). In similar vein, Li, Wei, and Liu, (2010) found positive relation between MO and Knowledge acquisition. Darroch's (2003) study has been proven the considerable relations betwixt knowledge collecting, generation and expansion. This is evident through the attempts of top management to enhance the significance interaction between MO and KS to realize suitable reactions to customers and market needs (González-Benito, González-Benito, \& Muñoz-Gallego, 2009; Zahra, 2008). Thus the following proposition is subtracted,

Proposition 2. Knowledge sharing and market orientation mainly contributes each other by generate and disseminate respective knowledge which offer customized products for customers and improve manufacturing process

\subsection{Market Orientation and Technological Innovation}

Among innovation antecedents in existing academic researches, MO has often been owned the solid relationship with firms' innovative efforts (Grinstein, 2008b; Olavarrieta \& Friedmann, 2008; Boso et al., 2012a; Wang \& Chung, 2013). The reason for this relationship backs to the role of MO in figuring a deeper understanding of customers' needs and minimizes the falling in innovation failures (Cooper, 1994; Atuahene-Gima, Slater, \& Olson, 2005). Hence, the firms that possess a powerful MO are looking carefully to their customers' manifest wants and react by develop their product and process to meet these wishes (Baker \& Sinkula, 2007, 2009). Over time; new segments of customers appear to represent the focus point of the firms, with this regard, Beck et al., (2011) argued that MO positively linked with innovation given to MO role in determining the new customer segments and that result in development of novel products to satisfy their needs. Therefore, market oriented firms are more likely to engage in high level of innovation and new products developments (Grinstein, 2008a). In addition to promote their ability to understanding competitive situations (Jiménez-Jimenez et al., 2008). Thus, this study posit,

Proposition 3. Market orientation mainly contributes to technological innovation through better meeting customized products and process for customers

\section{Problem Description}

Owing to the deteriorating conditions of the industrial public sector (Tas, 2012) Kurdistan region of Iraq has witnessed a wide range of privatization for large governmental enterprises to overcome the problem of low level of performance and innovate new products; but such enterprises represent only small percentage in the structure of the industry, operating in the specific industrial areas, while small and medium enterprises (SMEs) comprise about 2607 industrial enterprises distributed in the three provinces of Kurdistan region (MTIKRG, 2013). In addition, the manufacturing sector did not cover the local market need for the past few period, as the local market depends almost entirely on imported goods, for example; the largest share approximately (44.4 per cent) of Jordanian exports went to Iraqi market (Al-Hyari, Al-Weshah, \& Alnsour, 2012) in addition to imports from other neighboring countries such as Iran, Turkey, and others countries as well. Along these lines, and based on Erbil Chamber of Commerce, the imports in 2011 were $(5,637,795)$ trillion Iraqi Dinar this amount increased up to $(7,542,295)$ trillion Iraqi Dinar in 2012; these figures come as a result of Kurdistan local market needs and the abundance of local and foreign trading companies, which are more than 3136 companies (KFCCI, 2012). This is evident through the official reports of development plan for the Kurdistan region which indicated that the 
percentage of industrial sector contribution did not exceed 4.08\% of GDP in Kurdistan region in 2007-2011 (Ministry of Planning, 2014)

In considering a proper means to dealing with the aforementioned identified problems; reviewing of the relevant literature revealed that firms that are vying within international marketplace are mostly have a pressing need to constant and rapid solutions in their performance (Teece, Pisano, \& Shuen, 1997). In view of these requirements, both practitioners and academicians have proclaimed for further innovation in both processes and products alike (Damanpour, 1991). Thus, the notion of KS have been admitted through wide stream of scholars as a critical determinant of innovation (Nonaka, Toyama, \& Nagata, 2000). The skilled firms in acquiring new knowledge and combine the present knowledge with the new one, such firms have a greater opportunity to develop innovations in their products and manufacturing process. In other words, enterprise that achieve felicitous learning process has a greater power and opportunity to implement new products and processes facilely (Cohen \& Levinthal, 1990; Jiménez-Jiménez \& Valle, 2011). While these former researches have debated KS as a critical factor for innovation, few efforts have made to practically research the nexus betwixt KS and TI among the Iraqi manufacturing SMEs. Along these lines,, SMEs necessitous to hold unique knowledge and deep understanding of their customers' needs and competitors' attitudes to be able to vie with the strongest and largest firms through possession of a high level of MO, because MO is typically engaged with producing something unprecedented in meeting market conditions. Thus, it is considered as a critical antecedent of innovation ( $\mathrm{Li}$, Wei, \& Liu, 2010; Wang \& Chung, 2013). Moreover, MO has interactive relationship with KS as the behavior of KS appeared to be significantly associated with the MO in SMEs (González-Benito et al., 2009; Kohli \& Jaworski, 1990; Zahra, 2008). Past studies (Grinstein, 2008a; Lin, Peng, \& Kao, 2008; Otero-Neira et al., 2009) have confirmed that firms with the low level of KS are lower likely to consider MO and innovation. Kohli and Jaworski (1990) provided evidence for the synergistic effect between KS and MO through their definition of MO as a process of collecting and sharing information concerning buyers and competitors, in an attempt to obtain competitive advantage through superior customer value and ongoing processes of innovation. However, the majority of former studies have been conducted in large-sized firms within stabilized economies and advanced nations. For that, it is paramount to extend the study on the mutual relationship between KS and MO and their contributions on TI within SMEs in developing economy like Kurdistan region of Iraq.

In general, it is equitable to infer that the nexus between the elements of KS, MO and TI are not well investigated and has not been comprehensively researched within the Iraqi context. In other meaning, there is a shortage in case studies that research linking among KS, MO and technological innovation. Thus, present study purports to pinpoint the interrelationships between KS process and market orientation and their role in enhancing technological innovations. Hence, considering all these issues, this study determines its subject "Critical Determinants of Technological Innovation" as statement of its problem.

\section{Research Method}

The proposed framework was examined through a multiple case studies, this approach is proper method when the unit of analysis is represented in a system of action rather than the viewpoint of individuals (Yin, 2009). Case study method has its advantage in providing an in-depth study of one or few themes in their real context, it is concerned with precise description of situations that relevant to the case (Cohen, Manion, \& Morrison, 2007). Nevertheless, the inability to generalize the reached result to other situations represents the main determinant of this method. Following Eisenhardt (1989), two-step approach has been used for sampling. We attempted to obtain a rather homogeneous group in terms of size (small and medium enterprise), nature of activities (only industrial firms), and sector (building materials) as they all operate in comparable environments which allows the possibility to verify the results of the analysis. SMEs possess certain features including; less bureaucratic, higher tendency to take risks, possession of a more specialized knowledge, faster reactions to the dynamic market demands. These characteristics allow SMEs to gain from external knowledge more effectively compared to their larger counterparts (Bigliardi \& Dormio, 2009; Westerberg \& Frishammar, 2012). Our aim was to explore only successful firms which achieved particular innovations to get a deeper understanding of knowledge sharing role in facilitating innovation. The aforementioned proposed framework gave us directive approach on the critical dimensions for our sampling methods.

\subsection{Unit of Analysis}

Two industrial SMEs have been selected to represent the units of analysis of this study, Case Alpha and Case Beta. Both working in the field of building materials industry, they are of the most important SMEs operating in the Kurdistan region of Iraq. Case Alpha is one of the most popular enterprises in the field of building materials that was established in Erbil, the capital of the region, in 2011. Despite the novelty of the enterprise; it was able 
to achieve a widespread in all parts of the region. Currently, it has around 29 full time workers and three production lines which produce around $(180,000,000)$ units per year which is one of the largest production capacities for SMEs in the region. Whereas, Case Beta established in 2009 in Sulaimaniya with production capacity of $(160,000,000)$ units per year, it has around 27 full time workers and two production lines. However, to ensure the confidentiality, the actual names of participant firms have changed, so that the results of analysis do not affect the reputation of the firms and their employees.

\subsection{Research Instrument and Data Collection}

To gain an in-depth understanding of knowledge sharing and market orientation activities, and to find out whether these activities enhance technological innovation. Various forms of data collection (which occurred in the mid of 2014) were applied, including semi-structured interviews, enterprise documents analysis and a review of official governmental reports. Data collection process was implemented within two phases, in the first phase, one of the authors gathered enterprise confidential data about technological innovation. In addition to academic articles, industry and media reports. Within the second phase of data collection process, three months have been spent by one of the authors to conduct interviews with persons who manage and perform the core work in the researched enterprises. These interviews gave exhaustive information on how KS activities enabled TI, and how these initiatives improved. To ensure the rigor and to carry out triangulation process, the data were verified by all respondents who involved in the case. However, within data analyzing, we found that in different events the interviewed persons had confirmed different mechanisms by which Knowledge sharing activities enhance technological innovation. Then, with the combination of market orientation, we amended the initial framework to submit a more inclusive framework in which the mutual interactions between KS and MO provide mechanisms to foster TI. On occasion where the researchers recognized some gaps between the experiential data and theoretical concepts, they amended and revisited the data by return to the respondents to collect additional data and explain the data that previously collected. We utilized codes grounded in data by integrated data acquired from aforementioned data sources, and then codes have been grouped into categories in order to match patterns between the cases and link these categories.

\section{Deductive Testing of Propositions}

After discussing the specificities of critical elements of TI in previous literature, we will now outline these elements of our cases along the proposed framework of TI. We will highlight the actions of KS and MO behaviors to provide the whole background of our analysis, although our analysis particularly concentrates on the propositions that reflect the relations of the model.

Proposition 1. Knowledge sharing mainly contributes to technological innovation by enhancing products and process that meet customers'needs

Progress in TI (e.g., products and processes innovations) are predominantly explained by two major categories of KS behavior, as it revealed in our interview statements. In particular, we coded causes as follows: collecting of knowledge (e.g., "We search constantly for relevant knowledge concerning our product and manufacturing process," firm Alpha), donating of knowledge (e.g., "If an employee obtains an serious facts and information he conveys that immediately to all other employees," firm Beta), and top management commitment for KS (e.g., "Emphasizes employees' cooperation to solve problems.," firm Beta), trust among employees, both firms (Alpha and Beta) plainly show that their technological innovation relies heavily on mutual trust among employees rather than their individually efforts to achieve innovation (e.g., "Our interaction to enhancing innovation in both product and process is characterized by mutual trust").

Despite the fact that the building and construction sector is not of sectors that witnessing rapid technological developments, we observe that concurrent technological innovations might be dependent almost entirely on the new knowledge gained from other workers. From Beta, for instance, we learn that flexible flows of knowledge can increases the level of sharing recent knowledge that combines with the prior knowledge that is formerly existent Which has a positive contribution on innovation.

Proposition 2. Knowledge sharing and market orientation mainly contributes each other by generate and disseminate respective knowledge which offer customized products for customers and improve manufacturing process

As we mentioned before, knowledge acquisition represents the starting point for employees learning process, these arguments have been confirmed as Beta's executive manager explained "We always take into account the considerations that may affect the way we interact with our customers and how to serve them". Furthermore, evidence from interviews indicates that successful product and process innovations in most cases stem from 
environmental changes in various aspects especially customers' attitudes (e.g., "We bring about a lot of information regarding trends in governmental codes, technological expansions, and economical directions in our marketplace," firm Alpha). With regard to the methods that pursued by employees to exchange their knowledge, periodic and daily meetings represent the best way to share knowledge among employees (e.g.," We always hold meeting at least once in every quarter to discuss market trends and developments," firm Alpha and Beta). We learn that Knowledge possessed by firms purposively and design for their customers' needs, can be a significant source of superior response to the environmental changes and enhancing technological innovation. Similar to prior innovation studies (Wu et al., 2013), the ideas, notions, and notices that firm receives from customers can accelerate determining customer needs and offer customized products for those customers as Beta executive manager told us: "Data related to customer satisfaction are disseminated at all levels in our enterprise on a regular basis". This result implied the idea that the firm that encourages cooperation with the external parties (e.g., customers and competitors) to acquire knowledge encourages at the same time its employees to take part the knowledge obtained from their working groups and other divisions, thus all individuals can obtain from the recent knowledge.

Proposition 3. Market orientation mainly contributes to technological innovation through better meeting customized products and process for customers

As described above, knowledge about customer leads to profound understanding of customers' needs and minimizes the falling in innovation failures, such knowledge contribute to firm's TI in different complementary ways, first, it enhance constant learning about consumers attitudes, technological developments and competitors of the market, second it has a positive influence on customers experience and attitudes through helping them to make better purchase decision. For example, in our cases they provide advice regarding the quantity and specifications of required materials that be more suitable to the design of the building. Such generated knowledge is very common among customers and each time they ask the firm to supply them with this knowledge, because it offers useful reference for them to buy. This is obvious through Alpha manager claims (e.g., "We are able to improve product design according to our customer needs") and ("We are very fast in adapting to the changes in the business context and customer needs"). We learn that our case firms have the ability to discriminate between technological innovation and substantial technological change that occur normally over time. This becomes obvious from Beta manager who stated: (e.g., "We periodically analyze the effect of the shift in the business environment in order to develop our products and manufacturing process to meet our customers' needs").

\section{Research Findings Summary}

This study presented a conceptual framework and developed three sets of propositions to describe the critical factors of TI through investigating the influence of KS and MO as determinants of enhancing TI within building materials SMEs, in addition to the mutual interaction between these determinants. We find out that KS (e.g., knowledge collecting and donating) among firms' employees contribute in progressing of TI in both aspects product and process (Proposition 1). Moreover, trust and robust social networks that based on mutual trust can be fertile environment for the generation, dissemination, and exchange of knowledge among employees. Such mutual interaction between KS and MO increasing value added that implicitly reflected in the concept of innovation through better responding to what customers might expect (Proposition 2). Furthermore, MO behavior (e.g., knowledge generation, dissemination, and responsiveness) contribute to enhancing TI through integrated mechanisms. Possessing knowledge about current and potential customers' needs can improve experience related to preferred products by customers and improve manufacturing processes that help to provide such products (Proposition 3).

\subsection{Theoretical Contributions}

First, the theoretical contributions of our study reflected in the connectivity betwixt knowledge sharing studies and TI literature. Our study detects the influence of each dimension of KS (e.g., collecting and donating of knowledge) on TI and the role of TI in adding value to the customers. As such, the mechanisms through which KS enhance TI were analyzed to provide a more inclusive comprehension of this process. Further, this study is an extension of previous studies. While most of these studies assert the essential role of exchange knowledge among employees to enhance TI (Hoarau \& Kline, 2014; Kamasak \& Bulutlar, 2010). Exchange knowledge with customers is oftentimes assumed to perform a limited role in these studies. This study asserts the effective role of customers in generating of knowledge for firms' TI. Second, the proposed framework has a possibility to be adopted in other contexts, despite this framework has developed in the context of building material industry, the essential role of knowledge about current and potential customers' needs in fact itself the main catalyst for TI in 
other context. Finally, concerning the market orientation, this study provides a complementary perspective between KS and MO by highlighting customers' role in generating the required knowledge for innovation and the role of knowledge sharing among employees in achieving responsiveness to customers' needs. In other words, utilizing the interaction between knowledge from customers (MO) and exchanging knowledge about customers (KS) has the potential role in fostering TI within the firms.

\subsection{Managerial Implications}

This study provides examined enterprises with several managerial implications. First, the complementary nature of knowledge sharing dimensions which depend mainly on knowledge collecting about customers and donating this knowledge require from these enterprises to go beyond just sharing knowledge among employees through considering their customers as significant resource of knowledge and extending their abilities to respond effectively to customers' needs by adding more values to their products in comparison to the rivals. Intrinsically, the proposed framework hopes to help examined enterprises to deal with different mechanism of knowledge generation, donation, and dissemination among employees to enhancing value added. Second, this study indicates that enterprises should actively encourage TI by taking advantage from mutual interaction between KS and MO to support value co-creation with their customers. As presented in the analysis, how case enterprises utilized from adopting the complementary mechanism between KS and MO actions to enable TI.

\subsection{Research Limitations and Future Prospects}

Despite its theoretical and managerial contributions, this study has its limitations that need to be highlighted. First, the study focused basically on only two cases of Alpha and Beta in building sector. Thus, discussing additional cases in other sectors and markets will assist to generalize the results of current study. More and more technological innovation are constituting today by changing traditional thoughts about products, manufacturing processes, and work styles (Kamasak \& Bulutlar, 2010). Such attitudes in manufacturing sector will offer a proper context for further studies. Second, this study focuses on the positive aspects of KS among employees that enhance innovation, and this is the reason behind our choice of successful enterprises. Despite the positive contribution that have been discussed in the present cases, it is worth mentioning there might be a negative implications through which KS could hinders achieving innovations. For instance, Bigliardi and Dormio (2009) argued, SMEs have often faced with some obstacles like dominance of new complex technologies on the manufacturing processes, or lack of necessary knowledge to develop new products that utilizing such technologies. An interesting future research trend is to explore the effects of such barriers of knowledge generation and dissemination by investigating less successful cases. Finally, generation and dissemination of knowledge about customers is a mechanism to raise performance and achieving competitive advantage (Kohli \& Jaworski, 1990; Sohail \& Daud, 2009). Thus, examining the consequences of TI on performance would be an important aspect in the context of future efforts.

\section{References}

Al-Hyari, K., Al-Weshah, G., \& Alnsour, M. (2012). Barriers to internationalisation in SMEs: Evidence from Jordan. Marketing Intelligence \& Planning, 30(2), 188-211. http://dx.doi.org/10.1108/02634501211211975

Aljanabi, A., \& Kumar, D. (2012). Knowledge sharing and its impact on innovation performance : A case study of teaching quality assurance program. Research Journal of Commerce \& Behavioural Science (RJCBS), 2(2), $14-23$.

Atuahene-Gima, K., Slater, S. F., \& Olson, E. M. (2005). The contingent value of responsive and proactive market orientations for new product program performance. Journal of Product Innovation Management, 22(6), 464-482. http://dx.doi.org/10.1111/j.1540-5885.2005.00144.x

Bakar, L. J. A., \& Ahmad, H. (2010). Assessing the relationship between firm resources and product innovation performance: A resource-based view. Business Process Management Journal, 16(3), 420-435. http://dx.doi.org/10.1108/14637151011049430

Baker, W. E., \& Sinkula, J. M. (2007). Does market orientation facilitate balanced innovation programs? An organizational learning perspective. Journal of Product Innovation Management, 24(4), 316-334. http://dx.doi.org/10.1111/j.1540-5885.2007.00254.x

Baker, W. E., \& Sinkula, J. M. (2009). The complementary effects of market orientation and entrepreneurial orientation on profitability in small businesses. Journal of Small Business Management, 47(4), 443-464. http://dx.doi.org/10.1111/j.1540-627X.2009.00278.x

Bear, M., \& Frese, M. (2003). Innovation is not enough : climates for initiative and psychological safety, process 
innovations, and firm performance. Journal of Organizational Behavior, 24(1), 45-68. http://dx.doi.org/10.1002/job.179

Beck, L., Janssens, W., Debruyne, M., \& Lommelen, T. (2011). A study of the relationships between generation, market orientation, and innovation in family firms. Family Business Review, 24(3), 252-272. http://dx.doi.org/10.1177/0894486511409210

Bigliardi, B., \& Dormio, A. I. (2009). An empirical investigation of innovation determinants in food machinery enterprises. European Journal of Innovation Management, 12(2), 223-242. http://dx.doi.org/10.1108/14601060910953988

Boso, N., Cadogan, J. W., \& Story, V. M. (2012). Complementary effect of entrepreneurial and market orientations on export new product success under differing levels of competitive intensity and financial capital. International Business Review, 21(4), 667-681. http://dx.doi.org/10.1016/j.ibusrev.2011.07.009

Bouncken, R. B., \& Kraus, S. (2013). Innovation in knowledge-intensive industries: The double-edged sword of coopetition. Journal of Business Research, 66(10), 2060-2070. http://dx.doi.org/10.1016/j.jbusres.2013.02.032

Camisón, C., \& Villar-López, A. (2012). Organizational innovation as an enabler of technological innovation capabilities and firm performance. Journal of Business Research, 67(1), 2891-2902. http://dx.doi.org/10.1016/j.jbusres.2012.06.004

Capon, N., Farley, J. U., Lehmann, D. R., \& Hulbert, J. M. (1992). Prohles of product innovators among large U.S. manufacturers. Management Science, 38(2), 157-170. http://dx.doi.org/10.1287/mnsc.38.2.157

Casimir, G., Lee, K., \& Loon, M. (2012). Knowledge sharing: influences of trust, commitment and cost. Journal of Knowledge Management, 16(5), 740-753. http://dx.doi.org/10.1108/13673271211262781

Celuch, K., \& Murphy, G. (2010). SME Internet use and strategic flexibility: The moderating effect of IT market orientation. Journal of Marketing Management, 26(1-2), 131-145. http://dx.doi.org/10.1080/02672570903574296

Chao, M. C. H., \& Spillan, J. E. (2010). The journey from market orientation to firm performance: A comparative study of US and Taiwanese SMEs. Management Research Review, 33(5), 472-483. http://dx.doi.org/10.1108/01409171011041901

Cheng, C. F., Chang, M. L., \& Li, C. S. (2012). Configural paths to successful product innovation. Journal of Business Research.

Chung, H. F. L. (2012). Export market orientation, managerial ties, and performance. International Marketing Review, 29(4), 403-423. http://dx.doi.org/10.1108/02651331211242638

Cohen, M. L., \& Morrison, K. (2007). Research Methods in Education (6th ed.). UK: Routledge Taylor \& Francis Group.

Cohen, W., \& Levinthal, D. (1990). Absorptive Capacity: A new perspective on learning and innovation. Administrative Science Quarterly, 35(1), 128-152. http://dx.doi.org/10.2307/2393553

Cooper, R. G. (1994). New products: The factors that drive success. International Marketing Review, 11(1), 60-76. http://dx.doi.org/10.1108/02651339410057527

Crossan, M. M., \& Apaydin, M. (2010). A multi-dimensional framework of organizational innovation: A systematic review of the literature. Journal of Management Studies, 47(6), 1154-1191. http://dx.doi.org/10.1111/j.1467-6486.2009.00880.x

Damanpour, F. (1991). Organizational innovation: A meta-analysis of effects of determinants and moderators. Academy of Management Journal, 34(3), 555-590. http://dx.doi.org/10.2307/256406

Darroch, J. (2003). Developing a measure of knowledge management behaviors and practices. Journal of Knowledge Management, 7(5), 41-54. http://dx.doi.org/10.1108/13673270310505377

Eisenhardt, M. (1989). Building Theories from Case. Academy of Management Review, 14(4), 532-550.

Foley, A., \& Fahy, J. (2009). Seeing market orientation through a capabilities lens. European Journal of Marketing, 43(1/2), 13-20. http://dx.doi.org/10.1108/03090560910923201

González-Benito, Ó., González-Benito, J., \& Muñoz-Gallego, P. A. (2009). Role of entrepreneurship and market orientation in firms' success. European Journal of Marketing, 43(3/4), 500-522. http://dx.doi.org/10.1108/03090560910935550 
Grinstein, A. (2008a). The effect of market orientation and its components on innovation consequences: A meta-analysis. Journal of the Academy of Marketing Science, 36(2), 166-173. http://dx.doi.org/10.1007/s11747-007-0053-1

Grinstein, A. (2008b). The relationships between market orientation and alternative strategic orientations: A meta-analysis. European Journal of Marketing, 42(1/2), 115-134. http://dx.doi.org/10.1108/03090560810840934

Hall, R., \& Andriani, P. (2003). Managing knowledge associated with innovation. Journal of Business Research, 56(2), 145-152. http://dx.doi.org/10.1016/S0148-2963(01)00287-9

Hoarau, H., \& Kline, C. (2014). Science and industry: Sharing knowledge for innovation. Annals of Tourism Research, 46, 44-61. http://dx.doi.org/10.1016/j.annals.2014.01.005

Hooff, B. V. D., Schouten, A. P., \& Simonovski, S. (2012). What one feels and what one knows: The influence of emotions on attitudes and intentions towards knowledge sharing. Journal of Knowledge Management, 16(1), 148-158. http://dx.doi.org/10.1108/13673271211198990

Hung, R. Y. Y., Lien, B. Y. H., Fang, S. C., \& McLean, G. N. (2010). Knowledge as a facilitator for enhancing innovation performance through total quality management. Total Quality Management \& Business Excellence, 21(4), 425-438. http://dx.doi.org/10.1080/14783361003606795

Inauen, M., \& Schenker-Wicki, A. (2011). The impact of outside-in open innovation on innovation performance. European Journal of Innovation Management, 14(4), 496-520. http://dx.doi.org/10.1108/14601061111174934

Jiménez-Jiménez, D., \& Valle, R. S. (2011). Innovation, organizational learning, and performance. Journal of Business Research, 64(4), 408-417. http://dx.doi.org/10.1016/j.jbusres.2010.09.010

Jiménez-Jimenez, D., Valle, R. S., \& Hernandez-Espallardo, M. (2008). Fostering innovation: The role of market orientation and organizational learning. European Journal of Innovation Management, 11(3), 389-412. http://dx.doi.org/10.1108/14601060810889026

Kamasak, R., \& Bulutlar, F. (2010). The influence of knowledge sharing on innovation. European Business Review, 22(3), 306-317. http://dx.doi.org/10.1108/09555341011040994

KFCCI. (2012). Kurdistan Region Companies Directory. Iraq Erbil: Kurdistan Federation Chamber of commerce and Industry/ Iraq.

Kohli, A. K., \& Jaworski, B. J. (1990). Market orientation : The construct, research proposition, and managerial implications. Journal of Marketing, 54(April), 1-18. http://dx.doi.org/10.2307/1251866

Lee, V. H., Leong, L. Y., Hew, T. S., \& Ooi, K. B. (2013). Knowledge management: A key determinant in advancing technological innovation? Journal of Knowledge Management, 17(6), 848-872. http://dx.doi.org/10.1108/JKM-08-2013-0315

Li, Y., Wei, Z., \& Liu, Y. (2010). Strategic orientations, knowledge acquisition, and firm performance: The perspective of the vendor in cross-border outsourcing. Journal of Management Studies, 47(8), 1457-1482. http://dx.doi.org/10.1111/j.1467-6486.2010.00949.x

Lin, H. F. (2007). Knowledge sharing and firm innovation capability: An empirical study. International Journal of Manpower, 28(3/4), 315-332. http://dx.doi.org/10.1108/01437720710755272

Lin, Peng, C., \& Kao, D. (2008). The innovativeness effect of market orientation and learning orientation on business performance. International Journal of Manpower, 29(8), 752-772. http://dx.doi.org/10.1108/01437720810919332

Liu, Z., \& Cui, J. (2012). Improve technological innovation capability of enterprises through tacit knowledge sharing. Procedia Engineering, 29, 2072-2076. http://dx.doi.org/10.1016/j.proeng.2012.01.264

Ministry of Planning. (2014). Development plan for the Kurdistan Region for 2015-2019. Erbil: Ministry of Planning-Kurdistan Region Government.

MTIKRG. (2013). Industrial Factories Directory. Kurdistan Region of Iraq - Erbil: Ministry of Trade and Industry Kurdistan Region of Iraq.

Ngo, L. V., \& O'Cass, A. (2013). Innovation and business success: The mediating role of customer participation. Journal of Business Research, 66(8), 1134-1142. http://dx.doi.org/10.1016/j.jbusres.2012.03.009

Nickerson, J. A., \& Zenger, T. R. (2004). A knowledge-based theory of the firm-The problem-solving 
perspective. Organization Science, 15(6), 617-632. http://dx.doi.org/10.1287/orsc.1040.0093

Nonaka, I., Toyama, R., \& Nagata, A. (2000). A firm as a knowledge-creating entity: A new perspective on the theory of the firm. Industrial and Corporate Changes, 9(1), 1-20. http://dx.doi.org/10.1093/icc/9.1.1

OECD. (2005). Oslo manual (pp. 1-90). Oslo. Retrieved from http://www.oecd.org/sti/inno/2367580.pdf

Olavarrieta, S., \& Friedmann, R. (2008). Market orientation, knowledge-related resources and firm performance. Journal of Business Research, 61(6), 623-630. http://dx.doi.org/10.1016/j.jbusres.2007.06.037

Otero-Neira, C., Lindman, M. T., \& Fernández, M. J. (2009). Innovation and performance in SME furniture industries: An international comparative case study. Marketing Intelligence \& Planning, 27(2), 216-232. http://dx.doi.org/10.1108/02634500910944995

Sánchez, J. H., Sánchez, Y. H., Collado-Ruiz, D., \& Cebrián-Tarrasón, D. (2013). Knowledge creating and sharing corporate culture framework. Procedia - Social and Behavioral Sciences, 74, 388-397. http://dx.doi.org/10.1016/j.sbspro.2013.03.029

Sen, B. (2010). Theory, research and practice in library management 8: Market orientation. Library Management, 31(4/5), 344-353. http://dx.doi.org/10.1108/01435121011046380

Sohail, M. S., \& Daud, S. (2009). Knowledge sharing in higher education institutions: Perspectives from Malaysia. Vine, 39(2), 125-142. http://dx.doi.org/10.1108/03055720910988841

Szulanski, G., Cappetta, R., \& Jensen, R. J. (2004). When and how trustworthiness matters: Knowledge transfer and the moderating effect of causal ambiguity. Organization Science, 15(5), 600-613. http://dx.doi.org/10.1287/orsc.1040.0096

Tas, D. (2012). Endemic corruption in the Iraqi public sector: Can anti-money laundering measures provide the cure? Journal of Money Laundering Control, 15(4), 458-482. http://dx.doi.org/10.1108/13685201211266033

Teece, D. J., Pisano, G., \& Shuen, A. (1997). Dynamic capabilities and strategic management. Strategic Management Journal, 18(7), 509-533. http://dx.doi.org/10.1002/(SICI)1097-0266(199708)18:7<509::AID-SMJ882>3.0.CO;2-Z

Tsiotsou, R. H., \& Vlachopoulou, M. (2011). Understanding the effects of market orientation and e-marketing on service performance. Marketing Intelligence \& Planning, 29(2), 141-155. http://dx.doi.org/10.1108/02634501111117593

Wang, \& Han, Y. (2011). Linking properties of knowledge with innovation performance: the moderate role of absorptive capacity. Journal of Knowledge Management, 15(5), 802-819. http://dx.doi.org/10.1108/13673271111174339

Wang, C. L., \& Chung, H. F. L. (2013). The moderating role of managerial ties in market orientation and innovation: An Asian perspective. Journal of Business Research, 66(12), 2431-2437. http://dx.doi.org/10.1016/j.jbusres.2013.05.031

Westerberg, M., \& Frishammar, J. (2012). Innovation Performance. Journal of Small Business Management, 50(2), 283-309.

Wiklund, J., \& Shepherd, D. (2003). Knowledge-based resources, entrepreneurial orientation, and the performance of small and medium-sized businesses. Strategic Management Journal, 24(13), 1307-1314. http://dx.doi.org/10.1002/smj.360

Wu, J., Guo, B., \& Shi, Y. (2013). Customer knowledge management and IT-enabled business model innovation: A conceptual framework and a case study from China. European Management Journal, 31(4), 359-372. http://dx.doi.org/10.1016/j.emj.2013.02.001

Yin, R. (2009). Case Study Research Design and Methods (4th ed.). United Kingdom: SAGE Ltd.

Zahra \& George, G. (2002). Absorptive capacity: A review, reconceptualization, and extension. Academy of Management Review, 27(2), 185-203.

Zahra, S. A. (2008). Being entrepreneurial and market driven: implications for company performance. Journal of Strategy and Management, 1(2), 125-142. http://dx.doi.org/10.1108/17554250810926339

Zahra, S. A., Neubaum, D. O., \& Larrañeta, B. (2007). Knowledge sharing and technological capabilities: The moderating role of family involvement. Journal of Business Research, 60(10), 1070-1079. http://dx.doi.org/10.1016/j.jbusres.2006.12.014 
Zhang, J., \& Duan, Y. (2010). The impact of different types of market orientation on product innovation performance: Evidence from Chinese manufacturers. Management Decision, 48(6), 849-867. http://dx.doi.org/10.1108/00251741011053433

\section{Copyrights}

Copyright for this article is retained by the author(s), with first publication rights granted to the journal.

This is an open-access article distributed under the terms and conditions of the Creative Commons Attribution license (http://creativecommons.org/licenses/by/3.0/). 